E-JURNAL EKONOMI DAN BISNIS UNIVERSITAS UDAYANA
Available online athttps://ojs.unud.ac.id/index.php/EEB/index
Vol. 11 No.02, Februari 2022, pages: 153-168
e-ISSN: 2337-3067

\title{
ADOPSI TELEMEDICINE DI ERA NEW NORMAL
}

\section{Made Santika Dewi $^{1}$ Ni Nyoman Sunariani ${ }^{2}$}

\begin{tabular}{l}
\hline \multicolumn{1}{c}{ Article history: } \\
\hline Submitted: 30 Mei 2021 \\
Revised: 31 Juli 2021 \\
Accepted: 8 Agustus 2021 \\
\hline
\end{tabular}

Keywords:

Telemedicine;

Service Quality;

Technology Acceptance

Model;

Covid-19;

\section{Kata Kunci:}

Telemedicine;

Kualitas Layanan;

Model Penerimaan Teknologi;

Covid-19;

\section{Koresponding: \\ Universitas Pendidikan Nasional, Bali, Indonesia Email: \\ dewitika748@gmail.com}

\section{Abstract}

This research aims to determine and examine mountainously about the perception of medical personnel and patients through telemedicine service of the new normal era. This research used qualitative method with research subject namely doctor and patient. Data collection technique was carried out by in-depth interview. Researchers implement the adoption theory of Davis's technology and Zeithaml and Bitner's Servqual Technique. The result of data analysis in this study indicate that the quality of service through WhatsApp platform from the aspect of tangible, reliability, assurance and empathy are considered adequate especially non-emergency cases based on perceived ease of use, perceived usefulness, behaviour intention to use, actual system usage, attitude toward medical personnel have shown acceptance models upon non-emergency case.

Abstrak
Penelitian ini bertujuan untuk mengetahui dan mengkaji lebih
dalam mengenai bagaimana persepsi tenaga medis dan pasien
terhadap pelayanan melalui telemedicine di era new normal.
Penelitian ini menggunakan metode kualitatif dengan subjek
penelitian yakni dokter, dan pasien. Teknik pengumpulan data
dilakukan dengan wawancara mendalam. Peneliti menggunakan teori
penerimaan pemakaian terhadap suatu teknologi milik Davis dan
teknik Servqual milik Zeithaml dan Bitner. Hasil analisis data pada
penelitian ini menunjukkan bahwa kualitas pelayanan melalui
telemedicine dengan menggunakan media whatsapp dari aspek
tangible, reliability, assurance dan empathy sudah dinilai cukup baik
terutama pada kasus-kasus non emergency Berdasarkan aspek
perceived ease of use, perceived usefulness, behavioral intention to
use, actual system usage, attitude toward tenaga medis dinilai sudah
menunjukkan sikap penerimaann terutama pada kasus non
emergency.

Universita s Pendidikan Na sional, Bali, Indonesia ${ }^{2}$

Email: nyomansunariani@undiknas.ac 


\section{PENDAHULUAN}

Corona Virus Disease 2019 (COVID-19) telah dinyatakan oleh WHO (World Health Organization sebagai global pandemic, dan di Indonesia dinyatakan sebagai bencana nonalam berupa wabah penyakit sehingga memerlukan upaya pencegahan penularan dan penatalaksanaan pasien Covid-19 (Konsil Kedokteran Indonesia, 2020). Peningkatan jumlah kasus berlangsung cukup cepat, dan menyebar ke berbagai negara dalam waktu singkat. WHO melaporkan sampai tanggal 9 Juli 2020, sebanyak 11.858.283 kasus konfirmasi dengan 545.481 kematian di seluruh dunia (Case Fatality Rate/CFR 4,6\%) (WHO, 2012). Indonesia melaporkan kasus pertama pada tanggal 2 Maret 2020, meningkat dan menyebar dengan cepat di seluruh wilayah Indonesia. Saat ini, penyebaran COVID-19 dari manusia ke manusia menjadi sumber transmisi utama sehingga penyebaran menjadi lebih agresif. Transmisi COVID-19 dari pasien simptomatik (yang memiliki gejala) terjadi melalui droplet yang keluar saat batuk atau bersin (Susilo et al., 2020). Inilah sebabnya mengapa kita penting untuk menjaga jarak hingga kurang lebih 1 (satu) meter dari orang yang sakit (Kementerian Kesehatan RI, 2020). Orang yang paling berisiko tertular covid-19 adalah orang yang kontak erat dengan pasien COVID-19 termasuk dokter dan tenaga kesehatan lain yang memberikan pelayanan kesehatan oleh karena itu pemerintah menggencarkan penggunaan telemedicine dengan mengeluarkan surat edaran Menteri Kesehatan No 303 tahun 2020, tentang penyelenggaraan pelayanan kesehatan melalui pemanfaatan teknologi informasi dan komunikasi melalui telemedicine dalam rangka pencegahan penyebaran COVID-19 (Kementerian Kesehatan RI, 2020).

Telemedicine merupakan penggunaan teknologi informasi dan komunikasi untuk memberikan layanan medis dari jarak yang terpisah atau tidak ada tatap muka. Fasilitas komunikasi yang digunakan dapat berupa telepon, panggilan video, situs internet, atau alat komunikasi canggih lainnya. Komunikasi ini dapat terjadi antara dokter dan pasien, maupun antar tenaga kesehatan misalnya dalam konsultasi berjenjang dari dokter umum kepada dokter spesialis (Kuntardjo, 2020). Kewenangan dokter dalam memberikan pelayanan telemedicine meliputi anamnesa, pemeriksaan fisik tertentu yang dilakukan melalui audiovisual, pemberian anjuran yang dibutuhkan berdasarkan hasil pemeriksaan penunjang atau hasil pemeriksaan fisik tertentu, penegakkan diagnosis, penatalaksanaan dan pengobatan pasien, penulisan resep obat atau alat kesehatan, penerbitan surat rujukan jika diperlukan pemeriksaan lebih lanjut ke laboratorium atau fasilitas pelayanan kesehatan sesuai hasil penatalaksanaan pasien. Kerangka program telemedicine pada awalnya selama 5 tahun (2015-2019) diprioritaskan untuk Daerah Tertinggal Perbatasan dan Kepulauan (DPTK) dimana fasilitas keseh atan sangat sulit dijangkau oleh masyarakat, dan pada tahun 2020 telemedicine mulai digencarkan sebagai salah satu upaya untuk mencegah penyebaran virus COVID-19 (Kementerian Kesehatan RI, 2020). Asosiasi Modal Ventura Untuk Startup Indonesia (Amvesindo) mencatat bahwa kunjungan aplikasi kesehatan di Indonesia melonjak hingga 15 kali lipat (katadata.co.id, 2020). Para pengguna bisa memanfaatkan layanan konsultasi online dengan dokter, menebus resep obat, hingga membuat janji dengan dokter maupun rumah sakit hanya lewat satu aplikasi. Pengguna pun bisa mengakses berbagai artikel terkait seputar penyakit dan cara menghindarinya. Peningkatan signifikan terjadi pada aplikasi telemedicine yakni Halodoc. Mereka mencatat peningkatan pengguna aktif bulanan 10 kali lipat sejak pandemi merebak, jika dibandingkan dengan kuartal IV 2019 (katadata.co.id, 2020).

Penelitian sebelumnya mengenai Pemanfaatan Teknologi Informasi dan Komunikasi Pada Aplikasi Halodoc Sebagai Telemedicine Check Covid-19 dalam Upaya Preventif Penyebaran Virus Corona di Sleman Yogyakarta, telemedicine check covid-19 pada aplikasi Halodoc mampu membantu masyarakat sebagai bentuk upaya preventif penyebaran virus corona di Sleman, Yogyakarta proses komunikasi yang hanya berjalan mengandalkan teknologi berupa smartphone dan koneksi jaringan internet, terkadang menimbulkan hambatan bagi pengguna dalam pemanfaatan TIK seperti rasa 
ketidakpuasan, ketidakpahaman penggunaan teknologi, hingga sulitnya jaringan internet (Meyda Hanifah, 2020). Penelitian lain yang mengenai Pemanfaatan Telemedicine untuk Staf Medis Sebagai Dampak Revolusi Industri 4.0, penerapan telemedicine berdampak pada peningkatan kesehatan pasien dan keterampilan tenaga kesehatan dalam melakukan perawatan namun kesenjangan distribusi jaringan internet menjadi tantangan pemerintah dalam mengembangkan telemedicine (Nurhayati \& Imron, 2019). Di dalam pelaksanaannya, meskipun kecanggihan teknologi dilihat sebagai sebuah masa depan yang baik dalam pelayanan kesehatan, tetap saja masih sering terjadi kegagalan (Mauco KL, Scott RE, 2018). Kesuksesan program telemedicine terlihat dari meningkatnya tingkat konsultasi, penerimaan secara positif, dan keseluruhan umpan balik yang positif dari pasien (Dobke et al., 2011). Penggunaan teknologi dalam pelayanan kesehatan adalah sebuah perubahan yang besar dan perlu adanya adaptasi dan implementasi telemedicine atau telehealth tidak akan efektif apabila penyedia pelayanan kesehatan tidak siap dengan perubahan yang terjadi (Saleh et al., 2016).

Implementasi dari telemedicine atau telehealth memang tidak mudah dan berdasarkan data yang ada tingkat kegagalan yang terjadi adalah sebesar $70 \%$ dimana faktor utamanya adalah bukan karena kegagalan dari teknologinya melainkan karena kurangnya kesiapan dalam menggunakan teknologi yang ada (Mauco KL, Scott RE, 2018). Penghalang yang sangat krusial dalam mempengaruhi implementasi telehealth adalah penerimaan dari tenaga kesehatan (Irandokht Vahedi, 2017). Fenomena hubungan tatap muka antara pemberi dan penerima pelayanan kesehatan yang rawan selama pandemic covid-19 ini sangat mendorong masyarakat untuk bertransformasi di bidang pelayanan kesehatan. Kebutuhan akan pelayanan kesehatan yang cepat, efisien dan efektif merupakan tuntutan masyarakat saat ini. Hal tersebut telah membuat dunia kesehatan di Indonesia menjadi tertantang untuk terus mengembangkan kualitas pelayanan kesehatan terbaik dengan memanfaatkan teknologi informasi dan komunikasi melalui telemedicine. Salah satu instansi yang sudah menerapkan telemedicine adalah Bali Mitra Medical Center (BMMC). BMMC merupakan salah satu provider kesehatan yang memiliki beberapa klinik swasta yang bertempat dibeberapa hotel di Provinsi Bali. BMMC sudah menerapkan pelayanan melalui telemedicine dimulai dari bulan Agustus 2020. Berdasarkan fenomena yang sudah dipaparkan maka peneliti tertarik untuk meneliti hasil eksplorasi persepsi pasien dan tenaga medis mengenai pemanfaatan dan kualitas pelayanan telemedicine agar pelayanan dapat berjalan dengan efektif.

\section{METODE PENELITIAN}

Jenis penelitian yang digunakan adalah penelitian kualitatif yang bersifat deskriptif, yakni peneliti memahami fenomena tentang apa yang dialami oleh subjek penelitian secara holistik, dan deskripsi dalam bentuk kata-kata dan bahasa, pada suatu konteks khusus yang alamiah dengan memanfaatkan berbagai metode ilmiah (Moleong, 2007). Penelitian ini menggunakan teori penerimaan pemakaian terhadap suatu teknologi milik Davis dan teknik Servqual milik Zeithaml dan Bitner. Pada model TAM tingkat penerimaan penggunaan TI ditentukan oleh lima konstruk yaitu perceived ease of use (persepsi kemudahan), perceived usefulness (persepsi kegunaan), attitude toward using (sikap dalam menggunakan), behavioral intention to use (perilaku untuk tetap menggunakan), dan actual system usage (kondisi nyata penggunaan sistem) (Davis, 1989). Zeithaml dan Bitner (2006) dimensi-dimensi yang digunakan untuk mengetahui beberapa besar jarak harapan pelanggan dengan ekspektasi pelanggan terhadap pelayanan yang diterima dalam metode ini ada 5 yaitu tangibles, reliability, responsiveness, assurance, dan empathy.

Informan yang dipilih dalam penelitian ini yaitu informan yang dipilih dalam penelitian ini yaitu karyawan Hotel Como Shambala Estate Ubud, dan tenaga medis klinik BMMC. Tenaga medis dipilih karena peneliti ingin mendapatkan informasi mengenai pelayananan melalui telemedicine yang 
telah digunakan selama pandemi COVID-19 ini. Karyawan hotel yang juga merupakan pasien dari klinik BMMC dipilih karena peneliti ingin mendapatkan informasi mengenai kualitas pelayanan telemedicine yang telah digunakan selama pandemi COVID-19 ini. Wawancara dilakukan dengan durasi rata-rata 30 menit. Wawancara direkam dengan perekam audio handphone dan zoom atas ijin dari partisipan. Data dari audio tersebut kemudian diubah menjadi transkrip wawancara. Transkrip wawancara di baca dan direduksi dengan hati-hati untuk menentukan kode- kode yang dapat mewakili sekumpulan ide/pemikiran serupa. Kode-kode tersebut kemudian di kelompokkan menjadi satu tema besar. Beberapa tema tersebut dan kemungkinan hubungan antar tema diidentifikasi untuk dapat merumuskan suatu model yang dapat menggambarkan fenomena yang diteliti. Keseluruhan proses ini disebut dengan proses coding dan themeing yang dilakukan dengan bantuan spreadsheet Microsoft Excel. Kutipan-kutipan penting yang mewakili kode tertentu di dokumentasikan dalam kolom kode yang sesuai, untuk dapat dipergunakan dalam pembahasan hasil. Agar penyusunan laporan menjadi lebih efisien, masing partisipan diberi kode : Dokter 1 D1, Dokter 2 D2, Dokter 3 D3, Pasien 1 P1, Pasien 2 P2, Pasien 3 P3. Setiap kutipan yang dipaparkan dalam pemaparan hasil diakhiri dengan kode partisipan yang menyatakan pernyataan tertentu.

\section{HASIL DAN PEMBAHASAN}

Berdasarkan data yang diperoleh dengan metode wawancara dengan pasien mengenai kualitas pelayanan melalui telemedicine, terdapat keselarasan antara teori-teori yang digunakan sebagai berikut :

Tangibles atau wujud fisik merupakan bukti konkret kemampuan suatu perusahaan untuk menampilkan yang terbaik bagi pelanggan. Baik dari sisi fisik tampilan bangunan, fasilitas, perlengkapan, teknologi pendukung, hingga penampilan karyawan. Dari ketiga informan yang diwawancara, rata-rata menyampaikan hal yang sama terkait aplikasi whatsApp yang digunakan sebagai media untuk berkonsultasi dengan dokter memiliki tampilan yang menarik. Berikut adalah tanggapan dari P1 "Tampilannya sih sudah cukup jelas ya karena itu kan hmm... berupa chat-chat di whatsapp atau bisa telepon juga tampilannya sih jelas, jelas sih menurut saya, DP nya lumayan menarik hehehe". Tidak jauh berbeda dengan (P1) P2 mengatakan "Hmmm..ya karena cuman pake WA ya mungkin saya comment DP WA nya ya, yaa ... DP WA nya cukup menarik sih dan jelas dibaca tulisannya". Hal yang sama dengan (P2) juga disampaikan oleh $\mathrm{P} 3$ "Tampilan DP WA nya bagus sihhh menarik, tulisan juga jelas.

Reliability atau reliabilitas adalah kemampuan untuk memberikan layanan yang akurat tanpa membuat kesalahan apa pun dan dalam menyampaikan jasanya sesuai dengan waktu yang disepakati. P1 mengatakan "Gampang makek telemedicinenya soalnya tinggal ngechat aja, terus nunggu dibalas, puas lah sama pelayanannya, sejauh ini semua keluhan saya terjawab sih, jadwal telemedicine itu kan setiap hari dari jam 9 pagi sampai jam 6 sore tapi kalo bisa jamnya dipanjangin lagi karena beberapa kali saya mau pake telemedicine di jam malam itu ga bisa jadinya". Hal serupa dengan (P1) P2 mengatakan "Saya cuma lewat chat aja sih, cukup mudah sih konsultasinya, cukup puas dan jadwal telemedicinenya juga udah merangkul jam-jam efektive, keluhan saya terjawab semua dengan baik". Sedangkan P3 menyampaikan tanggapannya untuk menambah jam operasional pelayanan telemedicime "Hmmm kalo saya sih telemedicine itu mudah ya mudah banget ga berbelit belit lah makek telemedicinenya, apalagi zaman pandemic ini kan jadinya ga perlu datang ke RS dan sejauh ini seтиa keluhan dapat diatasi lah, terus mudahnya konsultasi sama aja kyak kita chatingan biasanya sama orang lain kan cuman lewat wa ya gampang lah, ga lewat platform-platform web atau aplikasi gitu, tapi jadwal telemedicinenya bisa diperpanjang lagi sampai jam 10 malam mungkin". Dari ketiga informan yang diwawancara, rata-rata menjawab sudah cukup puas karena pelayanan 
melalui telemedicine sangat mudah digunakan dan tidak berbelit-belit, semua keluhan terjawab dengan baik. Informan menambahkan saran untuk memperpanjang jam operasional telemedicine terutama pada jam malam.

\section{Responsiveness}

Responsiveness adalah tanggap memberikan pelayanan yang cepat atau responsif serta diiringi dengan cara penyampaian yang jelas dan mudah dimengerti. P3 mengatakan "Cukup mudah sih konsultasinya, sekian kali chat sama dokternya hmmm.jawaban yang saya dapet itu cepet cuman pernah agak terlambat dibalas karena dokternya masih sama pasien jadi karena sakit saya tidak begitu urgent jadi saya masih bisa nunggu dan itupun masih tetep di hari yang sama dijawabnya, dokter/perawat juga memberikan informasi sangat jelas mudah dipahami bahasanya". Tidak jauh berbeda dengan (P3) P2 juga memberikan tanggapannya, "Informasi yang saya dapet jelas sih cuman saya lebih prefer ya telpon aja langsung kalo ngetik ya lumayan makan waktu, ya biar ga ribet gituuu, cuman ya pastinya ga fast respon terus kan mungkin itu pas lagi periksa pasien dokternya jadi dibalesnya agak lama, kira-kira 30 menitan deh kyaknya".

Hal serupa dengan P2 juga disampaikan oleh P1 yang mengatakan "Cepet juga responnya pas dia (dokter) lagi sibuk dengan pasien mungkin dia minta waktu sebentar untuk memberi informasi karena lagi ada pasien dia (dokter) pasti bakal balik lagi dengan informasi itu, jelas kok informasi yang diberikan". Dari ketiga informan yang diwawancara, rata-rata menjawab layanan telemedicine memberikan informasi yang cukup jelas, tetapi layanan telemedicine memiliki kendala tentang kecepatan waktu dalam merespon keluhan meskipun sudah diberikan alasan yang jelas tetapi kecepatan daya tanggap dari pelayanan melalui telemedicine penting untuk keberlanjutan agar pasien tetap menggunakan pelayanan ini. Salah satu Informan juga memberikan tanggapannya tentang lebih memilih melakukan konsultasi via telepon dibandingkan chatting.

Assurance adalah jaminan dan kepastian yang diperoleh dari sikap sopan santun karyawan, komunikasi yang baik, dan pengetahuan yang dimiliki, sehingga mampu menumbuhkan rasa percaya pelanggan. P2 mengatakan "Hmm ramah sihh pas saya chat sama telpon ya sopan lah ngasih salam dulu, pas selesai telemedicine juga tetep kasih kyak ucapan terima kasih dan lain-lain gitu sih, sejauh ini cukup puas sih ya kebetulan juga konsul gejala-gejala ringan aja pas dikasih resep ngambil obatnya gampang, pengetahuan dokternya juga sudah cukup, ya aman juga kok kan semua pasti kesimpen di rekam medis saya". Hal serupa dengan (P2) disampaikan oleh P3 "pengetahuan dokternya juga sangat cukup, merasa aman dan percaya karena kan dokternya juga sudah tau juga riwayat sakitnya saya, dokter juga menunjukkan salam kok di awal dan diakhir".

Sedikit berbeda dengan (P2 dan P3) P1 mengatakan tanggapan tentang tidak merasa aman dan percaya menggunakan telemedicine pada kasus emergency "Hmmm..pengetahuan dokternya cukup karena beberapa kali saya tanya hal-hal berbeda lah, sakit-sakit yang berbeda ya masih bisa dibantu sama dokternya, tapi sebenernya sih kurang merasa aman dan percaya ya pada kasus emergency karena kan dokter kan tidak memeriksa secara langsung tapi di zaman pandemic ini ya kita mengurangi datang ke dokter kerumah sakit kalo misalnya penyakit-penyakit atau sakit-sakit yang masih bisa ditangani yang belum perlu ke dokter sih menurut saya sudah oke, dokternya juga ramah sih memberikan salam di awal dan diakhir". Dari ketiga informan keseluruhan mengatakan pelayanan sangat ramah, komunikasi, pengetahuan dan kemampuan yang dimiliki oleh dokter sudah cukup baik serta pengambilan obat yang cukup mudah. Mayoritas mengatakan aman dan percaya menggunakan telemedicine, tetapi salah satu informan menambahkan jika tidak merasa aman menggunakan aman dan percaya menggunakan telemedicine untuk kasus emergency .

Empathy adalah memberikan perhatian yang tulus dan bersifat pribadi kepada pelanggan, hal ini dilakukan untuk mengetahui keinginan konsumen secara akurat dan spesifik. P1 mengatakan "dokternya baik, mau meladeni konsultasi saya yang kadang saya nanya ini itu banyak deh pokoknya, 
perhatian dan bahasanya juga enak dibaca gampang jadinya saya cerna". Serupa dengan (P1) P2 mengatakan "bahasa dokternya gampang dimengerti dan beliau sangat care sekali apalagi dokternya udah saya kenal lama, dan semua keluhan selalu terjawab dengn baik". Tidak jauh berbeda dengan (P1 dan P2) P3 mengatakan "Dokternya ramah menunjukkan empathy lah ke saya, bahasanya mudah dipahami dokternya juga penuh perhatian, perhatian disini maksud saya perhatian biasanya sebagai dokter ke pasien, soalnya kadang saya cerewet juga heheheh...". Dari ketiga informan rata-rata menjawab dokter sangat memberikan perhatian, ramah dan diiringi dengan penyampaian bahasa yang mudah dimengerti.

Berdasarkan pemaparan diatas aspek tangible atau wujud fisik dalam penelitian ini menunjukkan bahwa media yang dipakai untuk pelayanan telemedicine adalah media yang mudah dan sudah sangat lumrah digunakan oleh sebagian besar masyarakat. Hal ini didukung oleh penelitian Giordano et al. dimana Whatsapp Messenger adalah salah satu aplikasi yang baik digunakan untuk komunikasi antara tenaga kesehatan dengan pasien hingga masyarakat umum (Giordano et al., 2017). Pelayanan telemedicine Klinik BMMC memiliki tampilan visual berupa display picture yang menarik, serta tulisannya yang mudah dibaca. Display picture berupa logo Klinik BMMC yang menampilkan jam operasional layanan sehingga memudahkan pasien untuk mengetahuinya. Hal ini didukung oleh penelitian Subroto yang menyatakan dimensi bukti fisik (tangibles) memiliki pengaruh yang signifikan terhadap kepuasan pasien di ruang VIP BLUD RSUD dr. Soemarno Sosroatmodjo Kuala Kapuas di mana semakin baik bukti fisik yang diberikan maka semakin tinggi pula kepuasan pasien (Subroto, 2018). Oleh karena suatu bentuk jasa yang tidak bisa dilihat, dicium, dan diraba maka aspek wujud fisik juga menjadi penting sebagai ukuran dari pelayanan yang diberikan. Pelanggan akan menggunakan indra pengelihatan untuk menilai suatu kualitas pelayanan yang telah diberikan.

Pada aspek reliability atau kehandalan dalam penelitian ini informan yang diwawancara, rata-rata menjawab sudah cukup puas karena pelayanan melalui telemedicine sangat mudah digunakan dan tidak berbelit-belit, semua keluhan terjawab dengan baik. Dimensi reliability juga membuktikan dan menggambarkan bahwa kemampuan dokter saat memberi pelayanan sesuai dengan harapan pasien. Semakin tinggi dimensi keandalan yang diberikan maka akan semakin tinggi pula kepuasan pasien. Dimensi keandalan penting untuk mencapai kepuasan pasien (Subroto, 2018). Klinik BMMC telah memberikan akses konsultasi online termudah dengan menggunakan media whatsapp sehingga pelayanan dari awal hingga akhir sangat mudah dilakukan oleh pasien tanpa langkah-langkah yang mempersulit pasien. Dalam hal ini perusahaan memberikan jasanya secara tepat semenjak pelanggan menggunakan jasanya pertama kali sampai berakhirnya penggunaan jasa tersebut (Wulan, 2011). Pada penelitian ini informan menambahkan saran untuk memperpanjang jam operasional telemedicine terutama pada jam malam hal ini mungkin dapat dipertimbangkan kembali oleh management Klinik BMMC. Hal tersebut didukung oleh Permenkes Nomor 20 Tahun 2019 dimana tercantum bahwa kewajiban Fasyankes pemberi konsultasi dalam melaksanakan pelayanan telemedicine memiliki kewajiban menyediakan waktu konsultasi 24 (dua puluh empat) jam dalam sehari, 7 (tujuh) hari dalam seminggu.

Pada aspek responsiveness atau daya tanggap berdasarkan data dari ketiga informan yang diwawancara, rata-rata menjawab layanan telemedicine memberikan informasi yang cukup jelas, tetapi layanan telemedicine memiliki kendala tentang kecepatan waktu dalam merespon keluhan meskipun sudah diberikan alasan yang jelas tetapi kecepatan daya tanggap dari pelayanan melalui telemedicine penting untuk keberlanjutan agar pasien tetap menggunakan layanan ini. Dalam situasi tertentu pelayanan telemedicine Klinik BMMC tidak merespon keluhan pasien dengan cepat, dokterpun sudah menginformasikan kepada pasien tentang keterlambatan tersebut dan masih dapat diterima oleh pasien. Jika dalam pelayanan konvensional berdasarkan Kemenkes RI No.129/Menkes/SK/IV/2008 pada pelayanan rawat jalan untuk indicator waktu tunggu pelayanan di rawat jalan yaitu $\leq 60$ menit 
dimulai dari pasien mendaftar sampai diterima/dilayani oleh dokter spesialis, diharapkan dengan pelayanan melalui telemedicine di Klinik BMMC waktu tunggu tidak lebih dari batas tersebut karen a menggunakan perangkat seluler sebagai media telemedicine ini didasarkan pada fleksibilitas dan kemampuannya untuk mengakses informasi dengan cepat. Membiarkan konsumen menunggu apalagi tanpa alasan yang jelas menyebabkan persepsi yang negatif dalam kualitas pelayanan (Tantarto et al., 2020). Salah satu Informan juga memberikan tanggapannya tentang lebih memilih melakukan konsultasi via telepon dibandingkan chatting. Pelayanan melalui telemedicine di Klinik BMMC terdiri dari beberapa pilihan antara lain, video call, voice call, dan chatting, pasien dapat memilih media apa yang ingin digunakannya senyaman mungkin untuk melakukan konsultasi melalui telemedicine. Dimensi daya tanggap ini merupakan dimensi paling dinamis, harapan pasien hampir dapat dipastikan akan berubah seiring dengan kecepatan daya tanggap dari pemberi jasa sehingga kecepatan daya tanggap harus selalu diperhatikan oleh Klinik BMMC dalam memberikan pelayanan melalui telemedicine.

Pada aspek assurance atau jaminan pada penelitian ini berdasarkan data Dari ketiga informan keseluruhan mengatakan pelayanan sangat ramah, komunikasi, pengetahuan dan kemampuan yang dimiliki oleh dokter sudah cukup baik serta pengambilan obat yang cukup mudah. Mayoritas mengatakan aman dan percaya menggunakan telemedicine. Salah satu informan memberikan tanggapan jika tidak merasa aman dan percaya menggunakan telemedicine pada kasus emergency, hal tersebut menunjukkan pelayanan kesehatan secara konvensional masih sangat dibutuhkan oleh pasien terutama pada kasus yang membutuhkan pemeriksaan fisk. Tetapi untuk kasus-kasus ringan (non emergency) keluhan-keluhan dalam pelayanan telemedicine Klinik BMMC dapat teratasi dengan baik. Keamanan menggunakan telemedicine juga sudah tercantum dalam Permenkes Nomor 20 Tahun 2019 yang menyebutkan "Fasyankes harus menjaga kerahasiaan data pasien, memberikan informasi yang benar, jelas, dapat dipertanggungjawabkan, dan jujur mengenai hasil konsultasi dan/atau Expertise kepada pasien". Hasil konsultasi yang memerlukan pemeriksan lebih lanjut akan diarahkan oleh dokter dalam pelayanan telemedicine ini. Ukuran kualitas yang menjadi kesan kepada konsumen tentang kualitas pelayanan jasa salah satunya merupakan aspek assurance (Tjiptono, 2015) . Aspek ini merupakan ukuran kualitas pelayanan yang berkaitan pada keahlian dalam menimbulkan kepercayaan serta keyakinan pada konsumen. Ukuran assurance atau kepastian meliputi kompetensi tenaga kerja pada pengetahuan produk mencangkup kemampuan petugas pada pengetahuan terhadap produk secara tepat, keramah-tamahan, perhatian dan kesopanan saat melayani konsumen, keterampilan memberikan keamanan dalam memanfaatkan pelayan an yang ditawarkan dan keterampilan dalam menumbuhkan rasa percaya konsumen pada jasa yang diberikan, termasuk jasa pelayanan kesehatan.

Pada aspek terakhir yaitu empathy berdasarkan data dari ketiga informan rata-rata menjawab dokter sangat memberikan perhatian, ramah dan diiringi dengan penyampaian bahasa yang mudah dimengerti. Dokter di Klinik BMMC dapat membangun hubungan komunikasi yang efektif dengan pasiennya sehingga banyak hal-hal negatif dapat dihindari. Dokter dapat mengetahui dengan baik kondisi pasien dan keluarganya dan pasien pun akan menumbuhkan kepada dokter. Kondisi ini akan berpengaruh pada proses penyembuhan pasien selanjutnya. Sikap empathy juga termasuk bagian dari terapi dokter ke pasien, karena dapat mengurangi kecemasan pada pasien. Saat pasien merasa dokter tersebut mengerti kondisi dan kekhawatirannya, pasien akan lebih nyaman dan percaya kepada dokter sehingga pasien patuh menjalankan petunjuk dan nasihat dokter karena yakin bahwa semua yang dilakukan adalah untuk kepentingan dirinya. Dimensi empathy merupakan aspek yang menekankan pada perhatian kepada konsumen serta bersifat individu kepada masyarakat untuk lebih mengetahui harapan atau kebutuhan masyarakat. Dimensi empathy berkaitan bagaimana petugas menanggapi keluhan dan masalah pasien, dan bagaimana petugas bisa mengenali pasien dengan baik. empathy 
sangat memerlukan sentuhan perasaan pribadi, aspek empathy merupakan aspek yang dapat menjadi kesempatan besar dalam membentuk pelayanan berbeda berupa suatu yang tidak diharapkan pasien tetapi diberikan oleh rumah sakit (Krismanto \& Irianto, 2020). Berdasarkan pembahasan diatas terkait kualitas pelayanan mengindikasikan bahwa semua indikator pada kualitas pelayanan sangat penting dalam pemenuhan kebutuhan, keinginan pelanggan, serta ketepatan penyampaiannya untuk mengimbangi harapan pelanggan terhadap penggunaan telemedicine. Temuan penelitian terhadap pelayanan telemedicine dengan menggunakan media whatsapp dari aspek tangible, reliability, assurance dan empathy dinilai sudah cukup baik terutama pada kasus-kasus non emergency. Tetapi yang harus dimaksimalkan lagi pada aspek responsiveness karena data dari ketiga informan menyatakanan layanan telemedicine memiliki kendala tentang kecepatan waktu dalam merespon keluhan meskipun sudah diberikan alasan yang jelas tetapi kecepatan daya tanggap dari pelayanan melalui telemedicine penting untuk keberlanjutan agar pasien tetap menggunakan pelayanan ini. Penambahan jam operasional pelayanan telemedicine yang menjadi saran dari informan juga hendaknya menjadi pertimbangan kembali oleh manajemen Klinik BMMC karena kesuksesan program telemedicine akan terlihat dari meningkatnya tingkat konsultasi, penerimaan secara positif, dan keseluruhan umpan balik yang positif dari pasien (Dobke et al., 2011).

Berdasarkan data yang diperoleh dengan metode wawancara dengan dokter mengenai penerimaan penggunaan telemedicine yang ditentukan oleh lima konstruk, berikut adalah penjelasan lebih detail mengenai kelima konstruk tersebut.

Perceived ease of use (persepsi kemudahan penggunaan) merupakan sebuah tingkatan dimana seseorang percaya bahwa penggunaan sistem tertentu, mampu mengurangi beban usaha dirinya dalam mengerjakan sesuatu. D1 mengatakan "Telemedicine disini sudah dirancang sedemikian rupa agar semudah mungkin dan trendnya saat ini yang sering digunakan oleh klien-klien kita itu adalah whatsapp dibandingkan dengan media social-media social lainnya seperti instagram, line atau mungkin platform yang lainnya jadi kebanyakan menggunakan whatsapp karena sudah biasa dipakai sehari-hari dan menurut saya sangat mudah digunakan, kalau mau follow up pasien juga gampang". D1 juga menambahkan tentang jaringan internet dalam penggunaan telemedicine "Kita selalu sih sedia pakai internet, jadi kita punya tablet (HP) khusus untuk telemedicine kemudian ada paket internet juga kalo pas habis paket internetnya kita menggunakan wifi provider di klinik jadi seperti itu ada plan a dan plan b jadi tidak ribet".

Serupa dengan (D1) D2 dan D3 menyampaikan hal serupa. D2 mengatakan "Menurut saya telemedicine yang menggunakan media whatsapp sebagai media untuk bertukar informasi jadi hmm sejauh ini merupakan media yang paling mudah untuk digunakan bahkan orang awam sekalipun misalkan telemedicine nya menggunakan zoom kemungkinan aksesnya lebih susah dibandingkan whatsapp jadi sejauh ini yang saya alami penggunaan telemedicine melalui whatsapp sudah sangat mudah di akses dan pengiriman informasi melalui whatsapp itu belum pernah ada gangguan". D2 juga menyampaikan tanggapannya mengenai follow up pasien "pake whatsapp itu gampang kita untuk follow up pasien tinggal chat aja kalau lewat platform lain seperti web dan lain-lain gak se gampang ini". D3 mengatakan "Kalo lebih mudahnya sih sebenernya lebih mudah ya kayak komunikasi pasien tuh gak terbatas jarak dan waktu lagi karena hmm sudah lebih gampang karena online, hmmm.. kalo selama aku kan kalo karena aku pas di klinik itu pakek tabletnya (HP) soalnya itu juga tabnya pakek kuota internet sendiri kan dan kalo habis bisa pake wifi klinik jadi oke-oke aja sih selama ini cuman pernah beberapa kali kuotanya habis tapi itu tuh minta staff beliin kuota trus udah enggak pernah gak ada kendala berarti sih kalo dari jaringan internetnya". D3 juga menambahkan "Ya kalau tanya tentang follow up ya jelas lebih gampang lah kalau pake whatsapp”. Dari ketiga informan rata-rata menjawab penggunaan whatsapp sebagai media untuk melakukan pelayanan telemedicine sangat mudah digunakan dan belum pernah terjadi kendala dengan jaringan internet karena selain 
menggunakan kuota internet di klinik juga tersedia wifi yang dapat digunakan. Informan juga menambahkan proses follow up pasien sangat mudah dilakukan menggunakan whatsappp dan hal tersebut belum tentu bisa dilakukan dengan mudah pada platform lain.

Perceived usefulness (persepsi kegunaan) sebagai "the degree to which a person believes that using particular system would enhance his or her job performance" yaitu suatu tingkatan dimana seseorang percaya bahwa penggunaan suatu sistem tertentu akan dapat meningkatkan prestasi kerja orang tersebut. Indikator persepsi kegunaan penggunaan (perceived usefulness) yaitu work more quickly (mempercepat pekerjaan), improve job performance (mengembangkan prestasi kinerja), effectiveness (efektivitas), increase productivity (menambah produktivitas), makes job easier (membuat pekerjaan lebih mudah) dan usefull (kegunaan) (Davis, 1989). D1 mengatakan "Kalo untuk gejala ringan ya, penyakit-penyakit yang ringan atau penyakit-penyakit yang tidak memerlukan pemeriksaan secara langsung, telemedicine itu effective digunakan apalagi di masa pandemic, sangat bagus dan mudah apalagi misalnya kualitas foto dan videonya juga bagus, contoh pada orang - orang yang bergejala ringan seperti nyeri tenggorokan mungkin kita agak susah melalui video, tapi kita bisa akali dengan minta tolong pasiennya untuk foto bagian tenggorokannya jadi nanti kirim ke telemedicine, itu akan sangat gampang kita tau, toh juga kita kalo melakukan pemeriksaan secara langsung, kita juga lihat tenggorokannya terus kita lakukan diagnose, tapi kalo lewat telemedicine ngasi resep obat gak semua bisa kasih". D1 menambahkan tentang kendala menggunakan telemedicine "jika ada kasus pasien baru dengan gejala penyakit kronis misalkan hipertensi dan diabetes militus itu belum bisa diresepkan langsung, kecuali pasien yang lama-lama yang sudah terdiagnosis dan rutin minum obat baru kita bisa resepkan".

Sementara D2 mengatakan telemedicine mempermudah pelayanan dalam kasus tertentu "Menurut saya telemedicine ini sangat mempermudah pelayanan dalam bidang kedokteran terutama pasien atau dokter yang tidak bisa bertatap langsung contohnya misalkan pasiennya berada di daerah singaraja kemudian dokternya ada di daerah Gianyar tentu saja apabila bertemu secara langsung itu sangat susah, dengan menggunakan telemedicine ini dokter dan pasien sangat dipermudahkan sekali untuk berkomunikasi, effective dan paling tidak hmmm history taking atau anamnesisnya bisa menggunakan telemedicine sangat dipermudah, untuk penegakkan diagnosis sekalipun antar dokter dan pasien hanya dengan menggunakan anamnesis sudah bisa tegak sekitar 70 sampai $80 \%$, sehingga dengan hanya menggunakan diagnosis melalui telemedicine ini sudah cukup menurut saya untuk menegakkan diagnosis yang ee diderita oleh pasien jadi kedepannya mungkin ee telemedicine ini bisa saya gunakan untuk melakukan konsultasi dengan pasien, terutama dengan gejala ringan, apabila pasien hmm mengalami gejala sedang hingga berat mungkin tidak bisa ya hanya anamnesis melalui telemedicine saja mungkin pasiennya sudah buru-buru diantar oleh keluarganya ke IGD, jadi pasien-pasien yang sebetulnya hanya dilayanai di poliklinik saja yang bisa menggunakan telemedicine". D2 juga memberikan tanggapannya mengenai peresepan obat "kalau lewat telemedicine ngasih resep obatnya ga sebebas pengobatan konvensional sih, mungkin itu susahnya".

Tidak jauh berbeda (D1 dan D2) D3 mengatakan "kalau gejala ringan sih sangat mudah dan membantu jadi gak perlu ketemu langsung dengan pasien tapi gak semua bisa kita periksa gitu kalau pake telemedicine kayak misalnya pernah eee aku dapet pasien dia itu kayaknya matanya kecakar sama anaknya itukan gak bisa kita periksa gitukan gaktau sedalem apa sebenernya lukanya dan kalo misalnya ke klinik kita pun kyaknya kalo misalnya lukanya dalem kan gak bisa diapa-apain jadi saya suruh ke igd gitu". Sama halnya dengan (D1 dan D2) D3 juga memberikan tanggapan terkait peresepan obat "telemedicine itu peresepan obatnya dibatasi, tidak boleh kalau golongan narkotika dan psikotropika". Dari ketiga informan rata-rata menjawab pelayanan melalui telemedicine cukup effective hanya pada pasien dengan kasus-kasus ringan sehingga dapat meminimalisasi kontak langsung dengan pasien untuk menghindari penyebaran virus COVID-19. Tetapi telemedicine juga 
memiliki keterbatasan selain keterbatasan pemeriksaan fisik, telemedicine juga memiliki keterbatasan pada peresepan obat sehingga tidak semua pasien yang melakukan konsultasi melalui telemedicine bisa mendapatkan resep/obat seperti pada pelayanan konvensional.

Sikap terhadap pengaplikasian (attitude toward using) dalam TAM dikonsepkan sebagai sikap terhadap penggunaan sistem yang berbentuk penerimaan atau penolakan sebagai dampak bila seseorang menggunakan suatu teknologi dalam pekerjaanya (Davis, 1989). D1 mengatakan "telemedicine merupakan suatu inovasi yang bagus ya jadi lebih aman lah dimasa pandemic kayak gini, tapi kalau disuruh milih saya tidak terlalu suka chatting karena hmmm di dunia kedokteran itu anamnesis itu sangat penting jadi kalo chatting itu selain wasting time menurut saya kadang itu bisa terjadi miss komunikasi kalau miss komunikasi terjadi diagnosis bisa beda, diagnosis beda treatment bisa beda jadi kalau saya, saya pakai telemedicine lebih senengnya kalo engga video call atau telpon melalui WA".

Berbeda dengan (D1) D3 mengatakan lebih menyukai konsultasi via chatting dibandingkan telepon/video call"memang sih lebih aman ya sekarang kalo telemedicine karena kan keluhan pasien juga banyakan batuk pilek yang mengarah-ngarah kesana banyak OTG memang lebih berbahaya kalo ketemu pasien tapikan memang udah resiko dari pekerjaan kita gitu yah kalo aku sih mikirnya gitu, ya apalagi cuman pakai WA kan kalo aku sih lebih prefer ngetik ya daripada ee ngomong gitu soalnya eee lebih kayak apasih kayak lupa-lupa gitu kadang aku tuh jadi sambil berfikir sambil aku ngetik gitu jadi hmm biar gak kelewat tapi kalau misalnya pun pasiennya mau nelpon atau video call kan gak masalah sih sebenernya kalo ada yang kurang kan ntar bisa ditanyain lagi lebih gampang”. D2 mengatakan "Ee telemedicine merupakan salah satu inovasi yang bisa digunakan untuk meminimalisir kontak dengan pasien karena kita ketahui bahwa penyebaran virus corona itu bisa terjadi apabila pasien atau dokter tidak menggunakan APD yang lengkap ee minimal level 2 apabila bertatap muka secara langsung jarak antara dokter dengan pasien minimal 1 meter ee apabila menggunakan telemedicine jadi dokter dan pasien jaraknya berjauhan, sehingga kontak secara fisikpun dapat dihindari, dan kalo konsultasi mau via chatting, telepon atau video call menurut saya sama aja, ya cuman kalo chatting perlu effort lebih kan buat ngetik tapi lebih enak sih telpon aja". Berdasarkan data dari ketiga informan mayoritas menunjukkan sikap penerimaan mereka terhadap pelayanan telemedicine dimana rata-rata mengatakan lebih merasa aman menggunakan layanan telemedicine apalagi selama pandemic covid-19 ini, dan informan pun menjawab lebih suka dan memilih voice call daripada chatting dalam memberikan pelayanan karena via chatting menurut informan membutuhkan waktu untuk mengetik sedangkan jika melalui voice call, dokter dan pasien dapat berkomunikasi secara langsung tanpa menunggu waktu untuk mengetik pesan.

\section{Behavioral Intention To Use}

Behavioral intention to use merupakan suatu tingkatan seseorang mengenai rencananya secara sadar untuk melakukan atau tidak melakukan suatu perilaku di waktu yang akan datang yang telah ditentukan sebelumnya (Davis, 1989). Adapun indikatornya adalah kemungkinan akan menggunakan, tertarik menggunakan teknologi baru dalam waktu dekat ini, dan ingin menggunakan teknologi baru ketika ada kesempatan (Davis, 1989). D1 mengatakan "Jadi eee kalau ditanya kedepannya akan melakukan telemedicine terus dan lain sebagainya saya yakin kedepannya itu kita harus bersahabat dengan teknologi saya akan terus melakukan telemedicine karena walaupun pandemic covid-19 itu akhirnya bisa kita kendalikan, kedepan sangat bagus sekali jika kita menggunakan telemedicine, itu juga sangat menghemat biaya". Tidak jauh berbeda deng an D1 (D2) mengatakan "Oke telemedicine ini merupakan salah satu modalitas yang sangat bagus diperg unakan memanfaatkan teknologi internet dan juga aplikasi teleconferrence untuk melakukan ee.. konsultasi online kemajuan dalam bidang teknologi ini sangat mendukung apabila pasien dan dokter ee jaraknya sangat jauh misalkan seperti saya katakan tadi pasiennya di singaraja dokternya di gianyar dengan 
telemedicine ini merupakan salah satu modalitas yang sangat bagus sekali untuk mempersingkat jarak dan juga waktu yang kita perlukan, cuma nanti untuk beberapa jenis penyakit yang non emergency saya rasa telemedicine ini bisa menjadi salah satu modalitas yang bisa dipakai di masa depan untuk konsultasi antara dokter dengan pasien".

Berbeda dengan (D1 dan D2) D3 mengatakan "Kalo untuk aku pribadi sih aku lebih prefer ketemu pasiennya langsung ya daripada pakai telemedicine, soalnya ya itu balik lagi karena kita meriksanya bisa lebih leluasa lebih bisa lah kita melihat-lihat pasien itu kyak gimana, ketemu sama pasien sebenernya walaupun dengan keadaan kayak gini yaudah pake aja APD dengan lengkap gitu kalo untuk apalagi setelah selesai pandemic aku sih prefer yaudah sih dateng aja gitu ke dokternya soalnya kalo misalnya periksanya gak bener-bener ntar takutnya miss ada miss dimana kan kita ya gak tau juga gitu keadaan pasien apalagi kalo pasiennya ntar bohong-bohong kan kita juga gatau ya mislanya kita tanya pernah ada ini ada sakit ini sakit ini taunya dia bohong tapi kalo misalnya kita eee misalnya kayak apaya dia bilang gak ada batuk pilek tapi pas di auskultasi ternyata ada ronchii itu kan kayak bisa bisa ketahuan dari pemeriksaan fisik gitu jadinya bukan sih mau mau ngejudge pasiennya bohong engga kan cuman lebih enak kalo ada pemeriksaan fisik gitu, tapi karena di klinik BMMC ini ada telemedicinenya jadi aku pakai sih kalo ada pasien yang milih layanan telemedicine itu”. Berdasarkan data dari informan mayoritas dokter menjawab akan menggunakan pelayanan telemedicine untuk kedepannya, tidak hanya selama pandemic COVID-19 terjadi. Tetapi salah satu informan menyampaikan lebih memilih pelayanan konvensional karena dapat melihat kondisi pasien lebih jelas.

Actual system usage adalah kondisi nyata penggunaan sistem dan dikonsepkan dalam bentuk pengukuran terhadap frekuensi dan durasi waktu penggunaan teknologi (Davis, 1989). Seseorang akan puas menggunakan sistem jika mereka meyakini bahwa sistem tersebut mudah digunakan dan akan meningkatkan produktifitas mereka, yang tercermin dari kondisi nyata penggunaan (Aritonang, 2019). D1 mengatakan "Eee.... saya jaga senin sampai jumat, hampir setiap jaga itu ada aja yang melakukan telemedicine, baik itu tentang pengobatan, baik itu misalnya obat-obatan antibiotika apakah boleh dan sebagainya, hampir setiap hari karena kebetulan pasien kita antusiasnya luar biasa jadi saya sering banget pakai telemedicine". D2 mengatakan "Ee selama saya praktek pada masa pandemic ee seminggu kurang lebih eee 4 sampai 5 orang pasien bisa contact atau konsultasi melalui telemedicine jadi hanya orang-orang yang berkeinginan konsultasi melalui whatsapp saja yang bisa menggunakan telemedicine ini jadi gak sering banget sih saya makek telemedicine, tapi saya harap masyarakata bisa lebih aware lah dengan makek telemedicine". Tidak berbeda dengan (D2) D3 mengatakan "Kalo di klinik ga setiap hari juga, seminggu ada 3 atau 4 kali gitu, tergantung pasiennya".

Berdasarkan data dari informan rata-rata mengatakan dalam seminggu ada saja pasien yang menggunakan layanan telemedicine sehingga informan terus menggunakan layanan telemedicine jika ada pasien yang memilih konsultasi menggunakan telemedicine. Salah satu informan juga mengharapkan agar masyarakat dapat lebih aware dengan kesehatan melalui telemedicine.

Berdasarkan pemaparan tersebut pada aspek perceived ease of use dari ketiga informan ratarata menjawab penggunaan whatsapp sebagai media untuk melakukan pelayanan telemedicine sangat mudah digunakan dan belum pernah terjadi kendala dengan jaringan internet karena selain menggunakan kuota internet di klinik juga tersedia wifi yang dapat digunakan. Informan juga menambahkan proses follow up pasien sangat mudah dilakukan menggunakan whatsappp dan hal tersebut belum tentu bisa dilakukan dengan mudah pada platform lain. Klinik BMMC memilih whatsapp sebagai media dalam pelayanan tersebut karena whatsapp merupakan aplikasi yang sangat mudah dan lumrah digunakan oleh masyarakat. Hal ini didukung oleh penelitian Giordano et al. dimana Whatsapp Messenger adalah salah satu aplikasi yang baik digunakan untuk komunikasi antara tenaga kesehatan dengan pasien hingga masyarakat umum (Giordano et al., 2017). Perceived ease of 
use disini mengacu pada keyakinan pengguna bahwa sistem teknologi yang digunakan tidak membutuhkan usaha yang besar saat digunakan. Pengguna mempercayai bahwa teknologi informasi yang lebih fleksibel, mudah dipahami dan mudah pengoperasiannya (compartible) sebagai karakteristik kemudahan penggunaan. Berdasarkan pemaparan tesebut jika individu menganggap media informasi mudah digunakan maka individu tersebut akan menggunakannya. Sebaliknya jika individu menganggap media informasi tidak mudah digunakan maka individu tersebut tidak akan menggunakannya.

Pada aspek perceived usefulness berdasarkan data dari ketiga informan rata-rata menjawab pelayanan melalui telemedicine cukup effective pada pasien dengan kasus-kasus ringan (non emergency). Menurut informan telemedicine juga dapat meminimalisasi kontak langsung dengan pasien untuk menghindari penyebaran virus COVID-19. Perceived usefulness dalam layanan telemedicine didefinisikan sebagai keyakinan dokter bahwa layanan telemedicine akan bermanfaat dan mempercepat pemberian perawatan, menghasilkan hasil kesehatan yang berkualitas, meningkatkan dokumentasi, mengurangi rujukan, dan meningkatkan pemantauan medis berbiaya rendah (Kissi et al., 2020). Akan tetapi temuan dalam penelitian ini telemedicine justru memiliki beberapa kendala yaitu yang pertama keterbatasan pemeriksaan fisik untuk penetapan diagnose pada kasus-kasus tertentu, penetapan diagnose pada kasus-kasus yang mengharuskan pasien untuk mengirim gambar harus memperhatikan pengaruh pencahayaan dan kontras dalam pengambilan gambar agar tidak terjadi kesalahan dalam penetapan diagnose dan treatment selanjutnya. Selanjutnya keterbatasan pada peresepan obat sehingga tidak semua pasien yang melakukan konsultasi melalui telemedicine bisa mendapatkan resep/obat seperti pada pelayanan konvensional. Pada aspek ini juga menekankan jika seseorang merasa percaya bahwa sistem berguna maka dia akan menggunakannya. Sebaliknya jika seseorang merasa percaya bahwa sistem informasi kurang berguna maka dia tidak akan menggunakannya (Santoso, 2010). Berdasarkan pemaparan diatas pelayanan melalui telemedicine dapat dikatakan cukup effective dan melengkapi fasilitas kesehatan konvensional terutama selama pandemi Covid-19 walaupun hanya pada kasus-kasus ringan yang tidak membutuhkan pemerikssaan fisik secara langsung.

Pada aspek attitude toward using kita dapat melihat sikap terhadap penggunaan sistem yang dapat berbentuk penerimaan atau penolakan sebagai dampak bila seseorang menggunakan suatu teknologi dalam pekerjaanya. Berdasarkan data dari ketiga informan mayoritas menunjukkan sikap penerimaan mereka terhadap pelayanan telemedicine dan mereka pun menjawab lebih suka dan memilih voice call daripada chatting dalam memberikan pelayanan karena via chatting menurut informan membutuhkan waktu untuk mengetik sedangkan jika melalui voice call, dokter dan pasien dapat berkomunikasi secara langsung tanpa menunggu waktu untuk mengetik pesan. Sikap dalam menggunakan teknologi didefinisikan sebagai cermin dari perasaan suka atau tidak suka terhadap suatu sistem dari target perilaku yang telah dilakukan (Santoso, 2010). Pada aspek ini mengindikasikan bahwa dalam pemberian pelayanan melalui telemedicine dokter selaku pemberi pelayanan kesehatan dapat memilih opsi yang disukainya dalam pemberian informasi.

Pada aspek behavioral intention to use berdasarkan data dari informan mayoritas dokter menjawab akan menggunakan pelayanan telemedicine untuk kedepannya, tidak hanya selama pandemic COVID-19 terjadi. Seseorang akan melakukan suatu perilaku (behavior) jika mempunyai keinginan atau minat untuk melakukannya. Minat perilaku dari pengguna tentu dipengaruhi oleh perceived usefulness serta perceived ease of use suatu sistem yang dijalankan. Berdasarkan pada perceived usefulness telemedicine dinilai cukup effective pada pasien dengan kasus-kasus ringan (non emergency). Telemedicine juga dapat meminimalisasi kontak langsung dengan pasien untuk menghindari penyebaran virus COVID-19, oleh karena itu mereka berminat untuk terus menggunakan telemedicine di masa mendatang dan merasa membutuhkan layanan telemedicine sebagai alternative di 
masa pandemic Covid-19 ini. Indonesia sebagai negara kepulauan, pemerataan dan keterjangkauan pelayanan kesehatan masih menjadi kendala (Ariyanti \& Kautsarina, 2017). Oleh karena itu telemedicine juga diperlukan sebagai penyelenggaraan pelayanan kesehatan jarak jauh oleh tenaga kesehatan dengan menggunakan teknologi informasi dan komunikasi, termasuk berbagi informasi tentang diagnosis, pengobatan, pencegahan penyakit dan cedera, penelitian dan evaluasi, serta pendidikan berkelanjutan kepada penyedia layanan kesehatan. untuk kepentingan peningkatan kesehatan individu dan masyarakat. Meskipun salah satu informan menyampaikan lebih cenderung ke pelayanan konvensional karena dapat melihat kondisi pasien lebih jelas tetapi ia tetap menggunakan layanan telemedicine pada saat bekerja jika ada pasien yang memilih melakukan layanan telemedicine. Layanan telemedicine telah membuktikan peranannya yang signifikan dalam melengkapi fasilitas kesehatan konvensional selama pandemi Covid-19 ini (Aliansi Telemedik Indonesia, 2020a).

Penggunaan teknologi sesungguhnya (actual technology use) berdasarkan data dari informan rata-rata mengatakan dalam seminggu ada saja pasien yang menggunakan layanan telemedicine sehingga informan akan terus menggunakan layanan telemedicine jika ada pasien yang memilih konsultasi menggunakan telemedicine. Salah satu informan juga mengharapkan agar masyarakat dapat lebih aware dengan kesehatan melalui telemedicine karena selain fleksibelitasnya, konsultasi melalui telemedicine juga dapat menghemat biaya perjalanan.

Berdasarkan pembahasan tentang pelayanan telemedicine oleh dokter terkait dengan penerimaan teknologi informasi dan komunikasi, penelitian ini mengindikasikan bahwa aspek-aspek dalam penerimaan teknologi merupakan hal yang harus diperhatikan dalam mengadopsi sistem teknologi, informasi dan komunikasi. Temuan penelitian dari aspek perceived ease of use, perceived usefulness, behavioral intention to use, actual system usage, attitude toward dinilai sudah menunjukkan sikap penerimaan oleh tenaga medis terutama pada kasus non emergency. Tetapi pada aspek perceived usefulness ditemukan beberapa keterbatasan-keterbatasan dalam menggunakan telemedicine, keterbatasan pemeriksaan fisik untuk penetapan diagnose pada kasus-kasus tertentu, penetapan diagnose pada kasus-kasus yang mengharuskan pasien untuk mengirim gambar harus memperhatikan pengaruh pencahayaan dan kontras dalam pengambilan gambar agar tidak terjadi kesalahan dalam penetapan diagnose dan treatment selanjutnya. Selanjutnya keterbatasan pada peresepan obat sehingga tidak semua pasien yang melakukan konsultasi melalui telemedicine bisa mendapatkan resep/obat seperti pada pelayanan. Temuan penelitian ini menekankan indikator perceived ease of use dan perceived usefulness adalah faktor utama yang menentukan perilaku penerimaan menekankan indikator perceived ease of use dan perceived usefulness adalah faktor utama yang menentukan perilaku penerimaan. Hal ini sesuai dengan teori TAM yang mengang gap bahwa 2 keyakinan individual, yaitu perceived usefulness dan perceived ease of use adalah faktor utama yang mempengaruhi perilaku penerimaan teknologi (Davis, 1989). Ketika pengguna tidak memiliki atau hanya memiliki sedikit pengalaman sebelumnya dalam menggunakan sistem, pengguna biasanya akan lebih memperhatikan kemudahan penggunaan sistem daripada kegunaannya, tetapi setelah terbiasa dengan sistem yang ada, kegunaan sistem menjadi perhatian utama untuk tetap atau tidak untuk terus menggunakan sistem. Pengguna merupakan kunci berhasil atau tidaknya suatu sistem yang diterapkan. Karena sebagus apapun sebuah sistem atau program yang dijalankan tidak akan berjalan dengan baik tanpa dukungan pengguna. Bila pengguna menganggap suatu sistem terlalu sulit untuk dijalankan atau menghambat kerja mereka maka sistem tersebut tidak akan digunakan dan akhirnya sia-sia.

Telemedicine telah mampu membantu negara ini khususnya di Indonesia dalam memberikan akses kesehatan yang merata bagi masyarakat, baik di kota besar maupun wilayah terpencil. Meskipun telemedicine telah membuktikan peranannya yang signifikan dalam melengkapi fasilitas kesehatan konvensional selama pandemi Covid-19 ini, harus tetap dipastikan bahwa pertumbuhan sektor ini berkelanjutan sehingga dapat terus membantu melengkapi sistem pelayanan kesehatan di 
tanah air. Program Pembangunan Perserikatan Bangsa-Bangsa (United Nations Development Programme/UNDP) telah bekerja sama dengan ATENSI (Aliansi Telemedis Indonesia) dalam sebuah langkah strategis yang perlu dilakukan untuk membangun ekosistem kesehatan yang lebih terpadu. Berdasarkan kesepakatan, UNDP dan ATENSI akan beraliansi untuk mendapatkan data dan informasi terverifikasi serta melakukan upaya advokasi bagi sektor ini (Aliansi Telemedik Indonesia, 2020b). Hal tersebut akan menjadi landasan bagi peraturan yang dibutuhkan untuk membuat ekosistem telemedicine di Indonesia semakin maju. Dengan adanya kerja sama ini, maka akan semakin banyak masyarakat Indonesia yang dapat memanfaatkan layanan telemedicine, dan terciptanya sektor telemedicine yang lebih terintegrasi di Indonesia.

\section{SIMPULAN DAN SARAN}

Berdasarkan hasil penelitian dan pembahasan mengenai kualitas pelayanan dan penerimaan telemedicine, maka dapat ditarik suatu kesimpulan bahwa kualitas pelayanan melalui telemedicine dengan menggunakan media whatsapp dari aspek tangible, reliability, assurance dan empathy sudah dinilai cukup baik terutama pada kasus-kasus non emergency. Tetapi yang harus dimaksimalkan lagi pada aspek responsiveness karena data dari ketiga informan menyatakanan layanan telemedicine memiliki kendala tentang kecepatan waktu dalam merespon keluhan meskipun sudah diberikan alasan yang jelas tetapi kecepatan daya tanggap dari pelayanan melalui telemedicine penting untuk keberlanjutan agar pasien tetap menggunakan pelayanan ini.

Berdasarkan aspek perceived ease of use, perceived usefulness, behavioral intention to use, actual system usage, attitude toward tenaga medis diniali sudah menunjukkan sikap penerimaann terutama pada kasus non emergency. Tetapi pada aspek perceived usefulness ditemukan beberapa keterbatasan-keterbatasan dalam menggunakan telemedicine, keterbatasan pemeriksaan fisik untuk penetapan diagnose pada kasus-kasus tertentu, penetapan diagnose pada kasus-kasus yang mengharuskan pasien untuk mengirim gambar harus memperhatikan pengaruh pencahayaan dan kontras dalam pengambilan gambar agar tidak terjadi kesalahan dalam penetapan diagnose dan treatment selanjutnya. Selanjutnya keterbatasan pada peresepan obat sehingga tidak semua pasien yang melakukan konsultasi melalui telemedicine bisa mendapatkan resep/obat seperti pada pelayan an. Temuan penelitian ini menekankan indikator perceived ease of use dan perceived usefulness adalah faktor utama yang menentukan perilaku penerimaan.

Berdasarkan hasil penelitian, pembahasan dan kesimpulan yang telah diuraikan, maka peneliti menyampaikan 3 saran untuk Klinik BMMC dan peneliti selanjutnya. Pelayanan dokter dalam pelayanan masih harus dimaksimalkan lagi sehingga keluhan pasien dapat ditanggapi dengan cepat, dan jam opersional telemedicine dapat ditambah sehingga mereka merasa puas pada pelayanan yang diberikan. Karena dalam penelitian ini penulis memiliki beberapa keterbatasan akibat pandemi covid19, maka disarankan para peneliti selanjutnya untuk meneliti atau menggali lebih dalam lagi mengenai pelayanan telemedicine dengan cakupan lebih luas misalnya di rumah sakit besar yang sudah mengadopsi telemedicine. Untuk peneliti selanjutnya dapat menggunakan teori-teori lain untuk menggali lebih dalam tentang pelayanan melalui telemedicine baik dari sisi tim medis maupun pasien. Hal ini akan lebih memperkaya hasil penelitian dengan mengambil fokus penelitian yang lain.

\section{REFERENSI}

Aliansi Telemedik Indonesia. (2020a). ATENSI dengan Menteri Kesehatan. https://atensi.or.id Aliansi Telemedik Indonesia. (2020b). UNDP dan ATENSI Berkolaborasi untuk Perkuat Industri Teleme disin Tak Hanya Saat COVID-19. 
Aritonang, R. P. ; S. ; R. K. (2019). Jurnal Teknologi, Kesehatan dan Ilmu Sosial Ka jian Tin gkat Kepuasan Mahasiswa Terhadap Sistem Informasi Berbasis Jurnal Teknolo gi, Keseha tan dan Ilmu Sosial. Teke snos, $1(1), 40-47$.

Ariyanti, S., \& Kautsarina, K. (2017). Kajian Tekno-Ekonomi pa da Telehealthdi Indonesia. Buletin Pos Dan Telekomunikasi, 15(1), 43-52. https://doi.org/10.17933/bpostel.2017.150104

Davis, F. D. (1989). Perceived Usefulness , Perceived , And User Acceptance. MIS Quarterly, 13(3), 319-339.

Dobke, M. K., Bhavsar, D., \& Herrera,F. (2011). Do telemedicine wound care specialist consults meet the needs of the referring phy sician? A survey of primary care providers. International Journal of Telemedicine and Applications, 2011.1-6 https://doi.org/10.1155/2011/321376

Giordano, V., Koch, H., Godoy-Santos, A., Dias Belangero, W., Esteves Santos Pires, R., \& Labronici, P. (2017). WhatsApp Messenger as an Adjunctive Toolfor Telemedicine: An Overview. Interactive Journal of Medical Research, 6(2), e11.https://doi.org/10.2196/ijmr.6214

Irandokht Vahedi. (2017). Applications of Telehealth in the Practice, Upgrading of Knowledge, and Communication of Physicians with their Colleagues and Patients in Canada.

katadata.co.id. (2020). Layanan Telemedicine Diprediksi Tetap Berkibar Usai Pandemi Berakhir. https://katadata.co.id/ameidyonasution/digital/5f45270a9ad78/layanan-tele med ic ine-dipredik si-tetapberkibar-usai-pandemi-berakhir

Kementerian Kesehatan RI.(2020). SuratEdaran Menteri Kesehatan RI HK.02.01/MENKES/303/2020tentang Penyelenggaraan Pelayanan Kesehatan Melalui Pemanfaatan Teknologi Informasi dan Komunika si Dalam Rangka Pencegahan Penyebaran Covid-19 tertanggal 29 April 2020. https://www.kemkes.go.id/article/view/20043000002/cegah-penyebaran-covid-19-pelayanan-kes ehatan dilakukan-melalui-telemedicine.html

Kissi, J., Dai, B., Dogbe, C. S. K., Banahene, J., \& Ernest, O. (2020). Predictive factors of physicians' satisfaction with telemedicine services acceptance. Health Informatics Journal, 26(3), 1866-1880. https://doi.org/10.1177/1460458219892162

Konsil Kedokteran Indonesia. (2020). Konsil Kedokteran Indonesia.

Krismanto, H., \& Iria nto, S. (2020). Analisis Kualitas Pela yanan Rawat Jalan Pada Rumah Sakit Umum Da erah (Rsud) Kota Dumai. Jurnal Manajemen Pelayanan Publik, 3(1), 32-48. https://doi.org/10.24198/jmpp.v3i1.26677

Kuntardjo, C. (2020). Dimensions of Ethics and Telemedicine in Indonesia: Enough of Permenke s Nu mber 20 Year 2019 As a Frame of Telemedicine Practices in Indonesia? Soepra, 6(1), 1-14. https://doi.org/10.24167/shk.v6i1.2606

Ma uco KL, Scott RE, M. M. (2018). Critical analysis of e-health readiness assessment frameworks: su itability for application in developing countries. Journal of Telemedicine and Telecare. 24(2). 1-10. https://doi.org/10.1177/1357633X16686548

Meyda Hanifah. (2020). Pemanfaatan Teknologi Informasi dan Komunikasi Pada Aplikasi Halod oc Se bagai Telemedicine Check Covid-19 dalam Upaya Preventif Penyebaran Virus Corona di Sleman Yogyakarta. Utilization of Information and Communication Technology in the Halodoc.

Moleong. (2007). Metode Penelitian Kualitatif.

Nurhayati, \& Imron, M. (2019). Utilization of Telemedicine for Medical Staff As a Impact of the Indu strial Revolution 4.0. International Conference of Health, Science and Technology 2019, 98-100.

Saleh, S., Khodor, R., Alameddine, M., \& Baroud, M. (2016). Readiness of healthcare providers for eHealth: the case from primary healthcare centers in Lebanon. BMC Health Services Research, 16(1), 1-11. https://doi.org/10.1186/s12913-016-1896-2

Santoso, B. (2010). Pengaruh Perceived Usefulness, Perceived Ease of Use, dan Perceived Enjoyment Terhadap Penerimaan Teknologi Informasi. Jurnal Studi Akuntansi Indonesia, 1998, 1-15.

Subroto,E. R. (2018). Pengaruh Data Tanggap, Bukti Fisik dan Operational Benevolence terhadap Kepuasan Pasien diruang VIP BludRSUD Dr.Soemamo Sosroatmodjo Kuala Kapus. 236-244.

Susilo, A., Rumende, C. M., Pitoyo, C. W., Sa ntoso, W. D., Yulianti, M., Herikurniawan, H., Sinto, R., Sin gh, G., Na inggolan, L., Nelwan, E. J., Chen, L. K., Widhani, A., Wijaya, E., Wicaksana, B., Maksum, M., Annisa, F., Ja sirwa n, C. O. M., \& Yunihastuti, E. (2020). Coronavirus Disea se 2019: Tinjauan Literatur Terkini. Jurnal Penyakit Dalam Indonesia, 7(1), 45. https://doi.org/10.7454/jpdi.v7i1.415

Ta ntarto, T., Kusnadi, D., \& Sukandar, H. (2020). Analysis of Service Quality Toward s Patient Sa tisfaction (Comparative Study of Patients Using Telemedicine Application and Face to Face Consultation in Healthcare). European Journal of Business and Management Research, 5(5), 1-7. https://doi.org/10.24018/ejbmr.2020.5.5.516

Tjiptono, F. (2015). Strategi Pemasaran.

WHO. (2012). Telemedicine: Opportunities and Developments in Member States: Report on the Second Glo bal Survey on eHealth 2009 (Global Observatory for eHealth Series, Volu me 2). He althcare Informatics 
Research,18(2), 153. https://doi.org/10.4258/hir.2012.18.2.153

Wulan, S. (2011). Analisis Kualitas Pela yanan Terhadap Kepuasan Pelanggan Pa da PT. Peru saha an Listrik Negara (Persero) Cabang Tanjungkarang. JurnalManajemen Dan Bisnis Universitas Bandar Lampung, 1(2), 11-20 